\title{
Investigation of the scintillation properties of plastic scintillator based on 2,5-diaryloxadiazole alkyl derivative
}

\author{
P.N.Zhmurin, D.A.Yelisieiev, O.V.Yelisieieva, \\ V.N.Pereymak, Yu.A.Gurkalenko \\ Institute for Scintillation Materials, STC "Institute for Single Crystals", \\ National Academy of Sciences of Ukraine, \\ 60 Nauky Ave., 61001 Kharkiv, Ukraine
}

Received June 15, 2018

\begin{abstract}
An activator is synthesized that could be dissolved up to $40 \%$ in a polystyrene matrix without precipitation of a single phase. Detailed studies of the spectral and scintillation properties of plastic scintillators activated by the new activator have been carried out. It is shown that while the concentration of the activator increases, the proportion of molecules bound to the associates increases as well. When the activator concentration is higher than $10 \%$, a slow component appears in the scintillation pulse as a result of triplet-triplet annihilation. According to the shape of the scintillation pulse, it is established that the lifetime of the triplet excited states in the new activator is about $10 \mathrm{~ns}$, what is not sufficient for obtaining a plastic scintillator with the effective neutron-gamma discrimination properties.
\end{abstract}

Keywords: plastic scintillator, scintillation process, triplet excited states.

Синтезирован активатор, способный растворяться в полистирольной матрице вплоть до $40 \%$ без выпадения отдельной фазы. Проведены детальные исследования спектральных и сцинтилляционных свойств полимерных основ пластмассового сцинтиллятора, активированных новым активатором. Показано, что при увеличении концентрации активатора растет доля молекул, связанных в ассоциаты. При достижении концентрации активатора выше $10 \%$ в сцинтилляционном импульсе в следствие триплет-триплетной аннигиляции появляется медленная компонента. По форме сцинтилляционного импульса установлено, что время жизни триплетных возбужденных состояний в новом активаторе составляет около 10 нс, что недостаточно для получения ПС с возможностью әффективного нейтрон-гамма разделения.

Дослідження сцинтиляційних властивостей пластмасового сцинтилятора на основі алкілпохідного 2,5-діарилоксадіазолу. П.М.Жмурін, Д.А.Єлісєєв, О.В.Єлісєєва, В.М.Переймак, ЮА.Гуркаленко.

Синтезовано активатор, здатний розчинятися у полістирольній матриці до $40 \%$ без випадання окремої фази. Проведено детальні дослідження спектральних та сцинтиляційних властивостей пластмасових сцинтиляторів, активованих новим активатором. Показано, що при збільшенні концентрації активатора зростає частка молекул, зв'язаних в асоціати. А при досягненні концентрації активатора вище 10 \% у сцинтиляційному імпульсі внаслідок триплет-триплетної анігіляції з'являється повільна компонента. За формою сцинтиляційного імпульсу встановлено, що час життя триплетних збуджених станів у новому активаторі становить близько $10 \mathrm{Hc}$, що недостатньо для отримання ПС з можливістю ефективного нейтрон-гамма розділення. 


\section{Introduction}

Plastic scintillators (PS) have quite long history and are quite wide used for high-energy particles registration. Usually, polystyrene and polyvinyltoluene are used as the polymeric PS base. The scintillation characteristics of standard PS, manufactured on their base, are well known [1]. However, modern requirements to detection devices created on their basis stimulate the search for new ways of modification of PS, which give new properties to PS. These requirements are, first of all, necessity of radiation hardness increase, giving to PS the ability of neutron registration, and improvement of the temporal characteristics [2-4]. Such ways were found, and majority of them are based on significant increase of the activator concentration in the PS polymeric base up to several tens wt.\%. But quantity of available substances that are able to be dissolved in the PS polystyrene base in high concentrations is small. Thus, the issue of new activators synthesis, that are able to be dissolved in polystyrene at high concentration, as well as study of the scintillation properties of the created on their base PS remain important to choose of new ways of PS properties modifications. In the given work description of the scintillation properties of PS, containing 2-(4-tert-butylphenyl)-5- $m$-tolyl1,3,4-oxadiazole ( $t$ BuMePPD).

\section{Experimental}

Structural formula of the $t$ BuMePPD molecule and its spatial structure is presented in Fig. 1.

2-(4-tert-Butylphenyl)-5-m-tolyl-1,3,4-o xadiazole was synthesized accordingly to the scheme, shown in Fig. 2. For this, 4tert-butylbenzoic acid chloride (2) is ob-<smiles>Cc1cccc(-c2nnc(-c3ccc(C(C)(C)C)cc3)o2)c1</smiles>
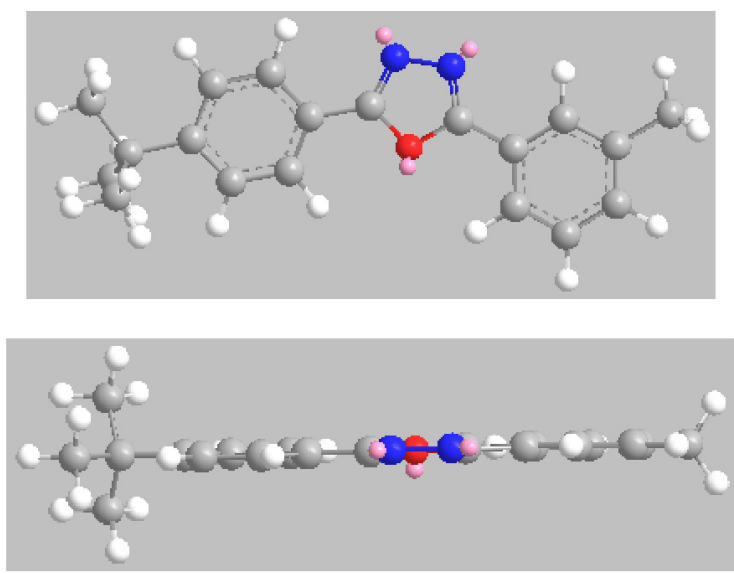

Fig. 1. Structural formula of the 2-(4-tertbutylphenyl)-5- $m$-tolyl-1,3,4-oxadiazole molecule and its spatial structure.

tained by heating of carboxylic acid (1) with a small surplus thionyl chloride. $m$-tolyl hydrazide (3) that was acylated with obtained acid chloride in pyridine medium at the temperature $0-20^{\circ} \mathrm{C}$. Formed in the previous stage diaroyl hydrazine (4) is boiled with a reflux condenser in thionyl chloride until stop of perceptible forming of gas reaction products, thionyl excess is distillated and obtained product is hydrolyzed with water. $t$ BuMePPD cleaning is carried out by recrystallization from isopropanol, and then chromatography on alumina oxide, eluent hexane. The obtained substance has the

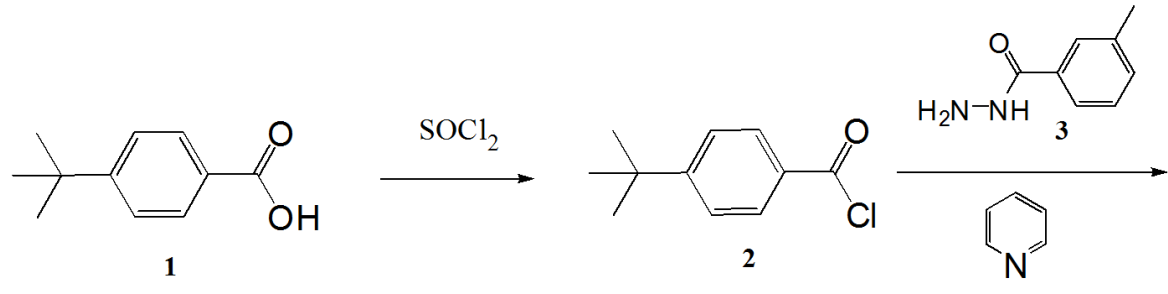

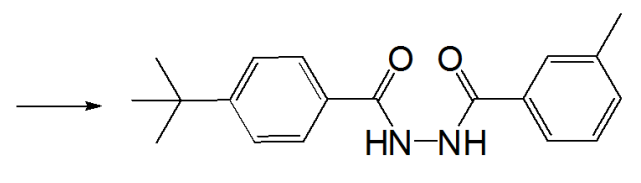

4

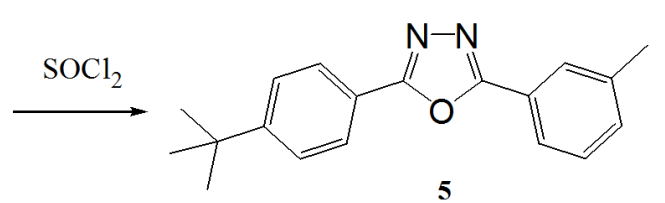

tBuMePPD

Fig. 2. Scheme of 2-(4-tert-butylphenyl)-5-m-tolyl-1,3,4-oxadiazole synthesis. 
melting temperature $72^{\circ} \mathrm{C}$, that can indirectly confirm good solubility in polystyrene.

For obtaining of scintillation compositions with different $t$ BuMePPD content in polystyrene base, required amount of $t$ BuMePPD was placed in a heat-resistant glass ampoule $25 \mathrm{~mm}$ in diameter, and added fresh distillated styrene to the solute of total mass of $50 \mathrm{~g}$. The ampoule was heated to $80^{\circ} \mathrm{C}$ in order to completely dissolve the additives, and purged with argon for $10 \mathrm{~min}$ to eliminate dissolved oxygen. Then the ampoule was sealed, placed into a thermostat, and kept at the temperature of $155^{\circ} \mathrm{C}$ for 7 days. Then the thermostat was cooled with the rate of $5^{\circ} \mathrm{C} / \mathrm{h}$ to $40^{\circ} \mathrm{C}$, after what the ampoule was taken out, cooled to the room temperature and a PS blank was taken out. Then PS samples were manufactured by mechanical tooling of the obtained blanks. As a result, transparent PS samples with $t$ BuMePPD content up to 40 wt. $\%$ were obtained. As a result $t$ BuMePPD did not drop into the separate phase at the given concentrations in the polystyrene matrix and could form only physically bonded aggregates on account of possible excitation energy transfer, but not chemically bounded aggregates [5].

The spectral luminescent characteristics of the samples were measured with a spectrofluorimeter Horiba JobinYvon Fluoromax-4.

Light yield measurements were performed by setting samples on the surface of PMT photocathode with immersion liquid and exciting with monoenergetic conversion electrons with the energy of $975 \mathrm{keV}$ from ${ }^{207} \mathrm{Bi}$ source. The light yield was determined by location of the peak, corresponding to electrons with the energy of $975 \mathrm{keV}$.

The temporal characteristics were determined by the photons correlated count method, using a two-channel setup with two PMT Hamamatsu 9800 in start and stop channel. In the measurements an electron source ${ }^{90} \mathrm{Sr}$ was used. As the start pulse, the Cherenkov radiation signal from polymethylmethacrylate sample was used. More detain description of the setup is presented in a work [4].

\section{Results and discussion}

The excitation and luminescence spectra of $t$ BuMePPD molecules in the polystyrene matrix have the clearly expressed maximum on the wavelength of $305 \mathrm{~nm}$ (Fig. 3), while the mean excitation band of PPD molecules is located on the wavelength of $282 \mathrm{~nm}$ [6].

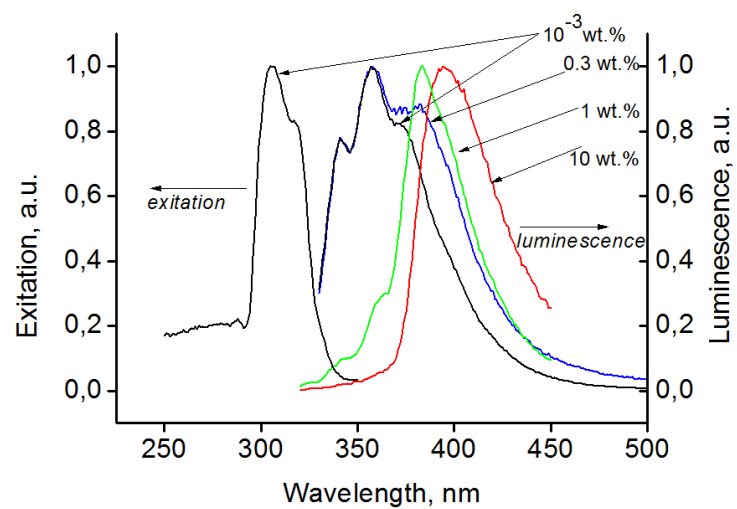

Fig. 3. Excitation and luminescence spectra of $t \mathrm{BuMePPD}$ molecules, dissolved in the polystyrene matrix.

It is seen, that addition of tert-butyl and methyl groups to the PPD molecule leads to additional polarization of its $\pi$-system, resulting in shift of the excitation and luminescence band to the long-wavelength range. The luminescent band maximum of $t$ BuMePPD molecules in polystyrene is shifted to $395 \mathrm{~nm}$ while the luminescent band maximum of PPD molecules is at $350 \mathrm{~nm}$. It seems evident that in $t$ BuMePPD molecule, substitutes significantly polarize the molecule, what leads to modification of its features.

With $t$ BuMePPD concentration increase, further transformation of the luminescent spectra is observed. At the concentration of 0.3 wt. $\%$ BuMePPD in the polystyrene matrix, appearance of the additional long-wavelength peak at $384 \mathrm{~nm}$ is detected (Fig. 3).

Since there is no change in the transparency of the samples due to possible origination of individual phases, the observed shift of the luminescence band is associated with the possibility of transfer of the excitation between the molecules, for example, due to the dipole-dipole interaction. Wherein, the splitting energy can be determined by the following expression [7]:

$$
\Delta E_{c o m}=E_{1}-E_{2}+\Delta D \pm \beta
$$

where

$\beta=\int d r_{1} d r_{2} \psi_{e}^{*}\left(r_{1}\right) \psi_{g}\left(r_{2}\right) V_{d-d}\left(r_{1}, r_{2}\right) \psi_{g}\left(r_{1}\right) \psi_{e}^{*}\left(r_{2}\right)$,

and $V_{d-d}\left(r_{1}, r_{2}\right)$ the dipole-dipole or another interaction energy.

Using this expression, it is possible to estimate the binding energy of the formed associate at the level of $1800 \mathrm{~cm}^{-1}$ or $0.22 \mathrm{eV}$. 


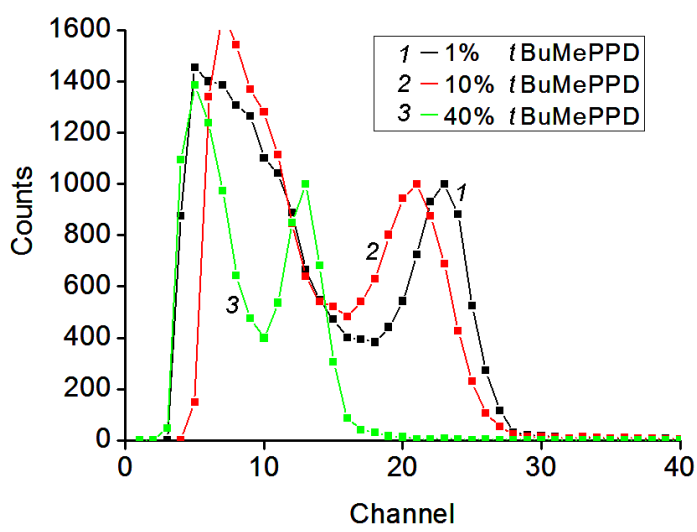

Fig. 4. The light yield of polystyrene samples with different $t$ BuMePPD concentrations at irradiation with monochromatic electrons with the energy of $975 \mathrm{keV}$ from a ${ }^{207} \mathrm{Bi}$ source.

It should be emphasized that the transition from a lower energy level, that has arose as a result of the interaction, can occur only due to the linear arrangement of the dipole moments of the optical transitions of the molecules, forming the associate. Thus the transition dipole moment must increase.

While concentration is increased, sharp rise of the number of molecules bounded into associates is observed, and already at the concentration of $1 \mathrm{wt} . \%$ practically all the molecules are combined into associates (Fig. 3). With further increase of the concentration, even greater shift of the luminescence band is observed, and at $10 \mathrm{wt} \%$, the maximum is observed at $395 \mathrm{~nm}$. While moving on the position of the line does not change at the $t$ BuMePPD concentration in polystyrene of up to $40 \mathrm{wt} . \%$. Since there is no sign of precipitation of a separate phase of $t$ BuMePPD in polystyrene at such high concentration, it can be assumed that the observed band shift may be due to the presence of an additional type of interaction to the dipole-dipole interaction between the associate molecules that could be the exchange interaction. In this case a delayed luminescence band associated with possible triplettriplet annihilation should appear in the luminescence decay kinetics.

All the obtained samples with different activation levels demonstrate the scintillation response, which has trend to decrease with increase of the concentration, as it is seen in Fig. 4. It is necessary to note that the maximal light yield at the $t$ BuMePPD concentration of 1 wt. $\%$ equals to half of the light yield of the standard plastic scin-

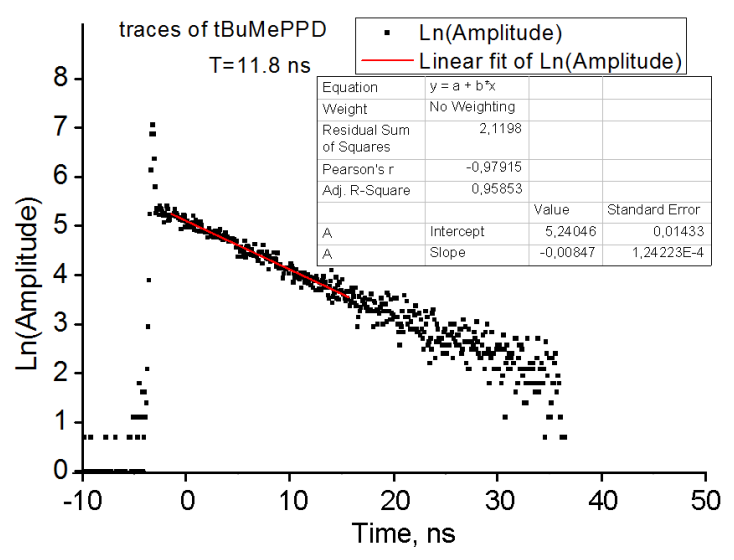

Fig. 5. Decay curve of scintillation pulse of polystyrene sample with $t$ BuMePPD concentration $10^{-3}$ wt. $\%$ under irradiation with electrons from ${ }^{90} \mathrm{Sr}$ source.

tillator on the polystyrene base, activated with $p$-terphenyl and POPOP.

All the samples don't have significant absorption bands in the luminescent band, what point to absence of any traps that were able to absorb excitation energy of the formed associates resulting in their light yield reduction. Such character of light yield decrease could be associated with an additional excitation energy transfer channel that was directly related to increase of the associate size. This channel can exist due to possibility of excitation energy transformation to triplet states of formed associate. Thus we performed detail investigations of decay curves of the scintillation response of samples. In the decay curve of sample of polystyrene with minimal $t$ BuMePPD concentration (Fig. 5) it was found very fast part, related to origination of Cherenkov radiation and direct $t$ BuMePPD molecule luminescence.

At such activator concentration level, in luminescence spectrum of the samples only $t$ BuMePPD molecules luminescence band are presented (Fig. 3). The observed scintillation pulse decay curve is well described by exponential dependence with the lifetime of $11.8 \mathrm{~ns}$, which is due to $t$ BuMePPD molecules luminescence decay. But with concentration increase, the luminescence spectrum of activated samples is characterized by presence of an additional peak, associated with aggregation of $t$ BuMePPD molecules. In this case, significant modification of the scintillation pulse decay curves is observed. Fast scintillation component arises (Fig. 6).

The obtained temporal dependence is well described with two exponential lifetimes of $\tau_{1}$ $\sim 1 \mathrm{~ns}$ and $\tau_{2} \sim 6 \mathrm{~ns}$. I.e., in the luminescence 


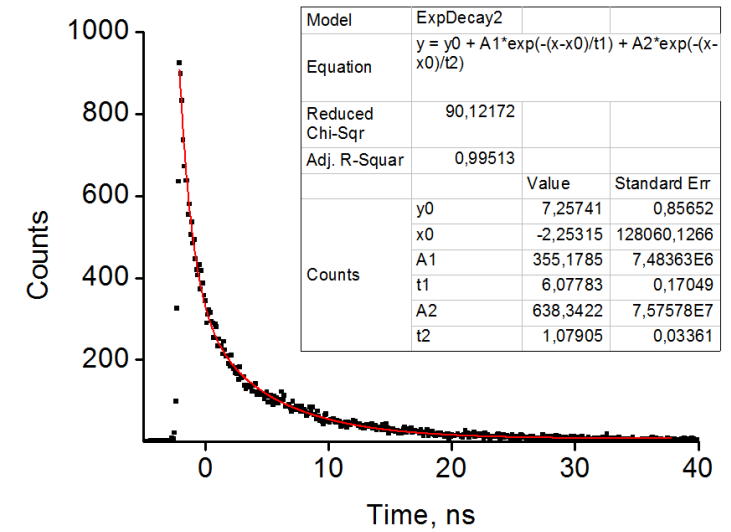

Fig. 6. The scintillation pulse decay curve of polystyrene samples with the concentration of 0.3 wt. $\%$ BuMePPD under irradiation with electrons from ${ }^{90} \mathrm{Sr}$ source.

spectra at the given concentrations, two peaks are clearly seen, the first is related to single $t$ BuMePPD molecules luminescence, and the second - to molecule associates. Thus, the second exponent can be related to quench single $t$ BuMePPD molecules luminescence, while the fast component - to their associates. With concentration increase more than $1 \mathrm{wt.} \%$, the luminescence spectrum is presented with single luminescent band, which at the concentrations more than 10 wt. $\%$ has even more low-energy state. And at the first sight, in this case the scintillation pulse must be presented with only single exponent. But the slow component is present in all curves together with fast component (Fig. 7).

While the fast component is well described by an exponential dependence with the decay time of about $1 \mathrm{~ns}$ (within error limits), the slow component with increasing concentration deviates from the exponential dependence with increased time. Therefore, we can assume that the fast component is associated with the luminescence of associates, in which there is certain quantity of coherently bound elements. In this case, the spontaneous emission time decreases in accordance with the formula $\tau_{c o h}=\tau_{0} / N_{c o h}$, where $\tau_{0}$ is the lifetime of the excited state of an individual molecule, and the $N_{c o h}$ is the number of coherently bound elements in the associate [8, 9].

Based on the expression presented, we can estimate the number of coherently bound molecules in the associate $N_{\text {coh }} \sim 10$. Thus, we can state that $t$ BuMePPD molecules in the polystyrene matrix are forming not only dimers, but associate large number of $t$ BuMePPD molecules, exceeding at least

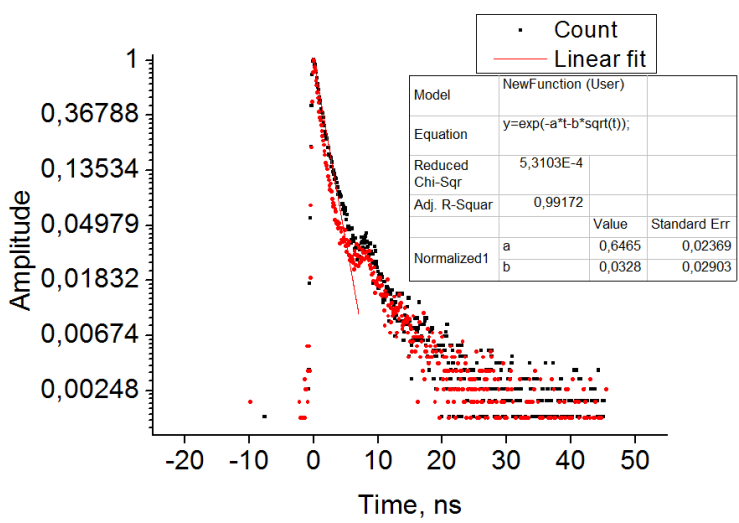

Fig. 7. The scintillation pulse decay curves of the polystyrene samples with the $t$ BuMePPD concentration of 10 and 40 wt. $\%$ under irradiation of electrons from a ${ }^{90} \mathrm{Sr}$ source.

10 molecules. The slow component, observed in the scintillation pulse for samples with the high activator concentration, is especially interesting. This component could be presented due to the triplet-triplet annihilation effect. The formation of triplet states is possible due to singlet-triplet transitions, as well as due to the features of the formation of the track in interaction of fast electrons with the polystyrene matrix. When the electron energy is lost, the track becomes more and more "dense", and the possibility of recombination of electrons with genetically unrelated holes increases, and consequently, during the annihilation of charges, leads to the possibility of triplet excited states formation. If exchange interaction between molecules is possible, then the triplet-triplet annihilation can occur, what leads to the appearance of so-called delayed luminescence.

In this case, the luminescence character can be approximately described as sum of two exponents, one of which determines the fast component, and another exponent in power equals to doubled triplet exited state decay rate - determinates the slow component [5].

Approximation of experimentally observed scintillation pulse curves for samples with the activator concentration of 10 and 40 wt. $\%$ demonstrates that the fast component remains at its lifetime about $1 \mathrm{~ns}$, while the slow one remains at about $5 \mathrm{~ns}$. (Fig. 7). In this figure we see that the lifetime of triplet states in associate remains at about $10 \mathrm{~ns}$ at room temperature.

Even presence of delayed luminescence with singlet states radiation doesn't allow us to use $t$ BuMePPD for creating of plastic scintillator for neutron-gamma discrimination due to the insufficient light yield of 
obtained samples. We observed that the light yield decreased with concentration increase. So, the main question for search of appropriate activator is "where is the excitation energy in highly activated scintillators spent?".

\section{Conclusion}

As a result of our work, we succeeded in synthesizing $t$ BuMePPD, that was able to be dissolved up to $40 \mathrm{wt} . \%$ in polystyrene, without falling out of the separate phase. We studied in detail the spectral and temporal characteristics of the scintillation pulse that is necessary in the search for polymeric structures capable of discriminating scintillation pulses produced by different particles.

\section{References}

1. J.B.Birks, The Theory and Practice of Scintillation Counting, Pergamon Press, London (1964).

2. V.G.Senchishin, F.Markley, V.N.Lebedev et al., Nucl. Instrum. Meth. A, 364, 253 (1995).

3. P.N.Zhmurin, V.N.Lebedev, V.D.Titskaya et al., Instrum. Methods Phys. Res.. A, 761, 92 (2014).

4. P.N.Zhmurin, D.A.Eliseev, V.N.Lebedev et al., Functional Materials, 23, 408 (2016).

5. M.Pope, C.E.Swenberg, Electronic Processes in Organic Crystals, Oxford (1999).

6. B.M.Krasovitskii, B.M.Bolotin, Organic luminophors, Chimia, Moscow, 1984 [in Russian].

7. M.Kasha, H.R.Rawls, M.Ashraf, Pure Appl. Chem., 11, 371 (1965),

8. J.Grad, G.Hernandez, S.Mukamel, Phys., 37, 3835 (1988).

9. F.C.Spano, J.R.Kuklinski, S.Mukamelb, J. Chem. Phys., 94, 7534 (1991). 